\title{
Poznavanje fizikalnih zakonitosti $u$ kreiranju fizioterapijskog procesa
}

1 Ivana Crnković

1 Dalibor Perković

1 Janko Babić

1 Danijela Dobrić

${ }^{1}$ Zdravstveno veleučilište Zagreb

\section{Sažetak}

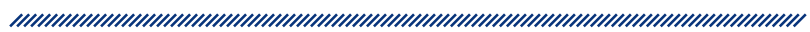

Fizika je jedna od ključnih prirodnih znanosti u fizioterapijskoj praksi. Cilj ovoga istraživanja bio je ispitati poznavanje i primjenu fizikalnih zakonitosti u fizioterapijskom procesu kod studenata preddiplomskog studija fizioterapije. $\mathrm{U}$ istraživanju su sudjelovala 92 studenta druge i treće godine, koji su položili ispit iz predmeta Fizika na prvoj godini studija. Za potrebe ovog istraživanja konstruiran je test čiji su zadaci tematski povezani s primjenom fizikalnih zakonitosti u kreiranju fizioterapijskog procesa.

Prema rezultatima, najviše studenata ima vrlo dobar $(39,1 \%)$ ili izvrstan $(43,5 \%)$ uspjeh postignut na predmetu Fizika. Percipiranu razinu znanja o utjecaju fizikalnih zakonitosti u svrhu objektivizacije i poboljšanja kvalitete fizioterapijskog procesa studenti ocjenjuju ocjenom dobar. Na ukupnom uzorku dvije trećine studenata smatra da je poznavanje fizikalnih zakonitosti važno ili vrlo važno u kreiranju fizioterapijskog procesa. Ukupno $60 \%$ studenata točno je odgovorilo na dva ili tri od mogućih pet pitanja na testu. Iz rezultata je vidljivo da u broju točnih odgovora postoji statistički značajna razlika s obzirom na godinu studija, pri čemu su studenti druge godine studija fizioterapije dali više točnih odgovora u odnosu na studente treće godine. Rezultati istraživanja ukazuju da ne postoji statistički značajna povezanost točnih odgovara studenata s njihovom završnom ocjenom, samoprocjenom znanja iz područja fizike te dostupnošću stručne i znanstvene literature.

Rezultati ovog istraživanja omogućuju izradu smjernica povezanih s oblikovanjem strategija za unaprjeđenje kvalitete nastavnog plana i programa predmeta Fizika na studiju fizioterapije u cilju primjene fizikalnih zakonitosti u fizioterapijskom procesu.

Ključne riječi: fizikalne zakonitosti, fizioterapijski proces, fizika

Datum primitka: 14.09.2017.

Datum prihvaćanja: 30.11.2017.

DOI: $10.24141 / 1 / 3 / 2 / 13$

Adresa za dopisivanje:

Ivana Crnković

+385914595737

ivana.crnkovic@zvu.hr

Zdravstveno veleučilište Zagreb

Mlinarska cesta 38

10000 Zagreb 


\section{Uvod}

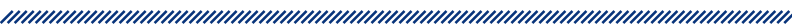

Fizioterapeut je zdravstveni stručnjak koji planira i provodi terapijske i rehabilitacijske postupke, primjenjujući znanja i vještine iz područja fizioterapije, kliničke kineziologije, osnovnih biomedicinskih znanosti, kliničke medicine i ostalih srodnih područja. Za odgovorno provođenje fizioterapijskog procesa fizioterapeut mora imati znanja i vještine koje mu omogućuju da na osnovi ciljane procjene postavi funkcionalnu dijagnozu i odredi fizioterapijsku intervenciju ${ }^{1}$. Uvođenjem suvremene tehnologije u sve segmente radnog procesa fizioterapeut se suočava $\mathrm{s}$ brojnim metodama fizioterapijske procjene i intervencije koja zahtijeva poznavanje mehanike i snalaženje u informatičkom okružju te na tržištu rada čiji se zahtjevi neprekidno mijenjaju. Automatizacijom radnog procesa u kliničkom okružju u radu fizioterapeuta smanjuje se tjelesno opterećenje, no i dalje je prisutno te je neizostavna karakteristika u radu s pacijentom. Tržište rada očekuje od fizioterapeuta sposobnost rješavanja problema u praksi (engl. problem solving), čime donošenje rješenja početnog zahtjeva nije direktno povezano s poznavanjem tradicionalnih znanstvenih i biomedicinskih disciplina. Trendovi u visokom obrazovanju u pristupu poučavanja stavljaju u središte studenta (engl. studentcentred approach). U Hrvatskom kvalifikacijskom okviru kompetencije u užem smislu odnose se na samostalnost i odgovornost, odnosno na sposobnosti koje jamče samostalnost i preuzimanje odgovornosti i koje u najvećoj mjeri razlikuju određene razine kvalifikacija ${ }^{2,3}$.

Osnovni su fizikalni zakoni koji se primjenjuju u fizioterapijskom procesu zakon poluge i princip rastavljanja sila. Riječ je o zakonitostima koje omogućuju upotrebu vrlo jednostavnih „mehanizama” za pojačavanje iznosa sile kojom se djeluje na neki dio ljudskog tijela ili kojom ljudsko tijelo djeluje na neki vanjski objekt. Princip poluge omogućuje jednostavno pojačavanje sile podešavajući udaljenost hvatišta sile od točke oslonca. Također je važan efekt koji vanjska sila može imati na ljudsko tijelo, to jest jedan njegov dio, i to najčešće na jedan mišić ili skupinu mišića: zahvaljujući velikim razlikama između udaljenosti hvatišta i oslonca, vanjska sila može proizvesti mnogostruko jaču silu koja onda djeluje na pojedine mišiće i kosti u ljudskom tijelu, i to najčešće kralježnicu i mišiće koji se nalaze oko nje.

Princip poluge temelji se na dvije sile koje su u ravnoteži ako je njihov omjer obrnut omjeru udaljenosti njiho- vih hvatišta od točke oslonca. Drugim riječima, sila od $10 \mathrm{~N}$ čije je hvatište jedan metar daleko od oslonca bit će u ravnoteži sa silom od $100 \mathrm{~N}$ čije je hvatište $10 \mathrm{~cm}$ udaljeno od točke oslonca. Slučaj koji se često događa u ljudskom tijelu prilikom podizanja tereta jest da ako čovjek podiže teret čije je težište jedan metar daleko od točke oslonca, sila kojom će mišić iza kralježnice morati djelovati kako bi održao ravnotežu, a čije je hvatište otprilike tri centimetra daleko od točke hvatišta - centra kralježnice - otprilike je 30 puta veća. Ako na ovakav način podižemo teret od $10 \mathrm{~kg}$, mišić djeluje silom koja je ekvivalentna masi od $300 \mathrm{~kg}$. Zbog toga, kao što znaju svi iskusni dizači i fizički radnici, teret mora biti što bliže kralježnici kako bi se smanjio krak sile i, posljedično, opterećenje mišića 4 .

Poznavanje fizikalnih zakonitosti kao što su princip poluge, razlikovanje jednokrake i dvokrake poluge, princip pojačavanja sile, razumijevanje kako se iznimno jednostavnim aparatom sila može pojačati nekoliko desetaka puta i kakve posljedice to može imati po okolna tkiva zasigurno su elementi koji unaprjeđuju kvalitetu fizioterapijske prakse. Poznavanje fizikalnih principa fizioterapeutu omogućuje u okviru fizioterapijskog procesa objektivniju fizioterapijsku procjenu i korekciju pojedinih fizioterapijskih postupaka ovisno o uvjetima rada. Nepoznavanje fizikalnih zakonitosti rezultira fizioterapijskim procesom uz slijepo pridržavanje propisanih fizioterapijskih procedura bez mogućnosti prilagođavanja parametara konkretnoj situaciji.

Cilj je ovog rada:

1. provjeriti elementarna znanja fizikalnih zakonitosti u cilju kreiranja fizioterapijskog procesa kod studenata fizioterapije

2. ispitati povezanost sociodemografskih karakteristika studenata fizioterapije i njihova dosadašnjeg uspjeha na predmetu Fizika u odnosu na razinu znanja fizikalnih zakonitosti u okviru fizioterapijskog procesa.

\section{Metode}

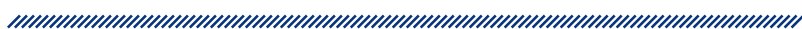

\section{Uzorak}

U istraživanju su sudjelovala 92 sudionika u dobi od 19 do 29 godina $(M=20,90)$. Većina sudionika bila je ženskog spola $(84,8 \%)$, dok su osobe muškog spola obu- 
hvaćale 15,2 \% uzorka. Ciljani uzorak bili su studenti druge i treće godine preddiplomskog studija fizioterapije Zdravstvenog veleučilišta u Zagrebu.

\section{Mjerni instrument}

U svrhu ovoga istraživanja primijenjen je upitnik o sociodemografskim podacima ispitanika koji sadrži pitanja o dobi, spolu, godini studija i završnoj ocjeni iz kolegija Fizika. Primijenjene su i dodatne čestice koje sadrže pitanja o procjeni znanja o utjecaju fizikalnih zakonitosti u svrhu objektivizacije i poboljšanja kvalitete fizioterapijskog procesa te dostupnosti stručne i znanstvene literature o ulozi fizikalnih zakonitosti u okviru fizioterapijskog procesa. Odgovori na pitanja o važnosti poznavanja fizikalnih zakonitosti bili su izraženi na 5-stupanjskoj skali Likertova tipa (1 - nije nimalo važno, 5 - iznimno je važno).

Mjerni instrument sastojao se od pet zadataka postavljenih u obliku pisanog testa koji su sudionici rješavali samostalno, pri čemu im je na raspolaganju bilo $30 \mathrm{mi}-$ nuta. Ispitivalo se znanje fizikalnih zakonitosti primjenjivih u fizioterapijskom procesu. U svakom zadatku bio je točan samo jedan odgovor. Odgovor u zadacima bio je izražen ili u kilogramima $(\mathrm{kg})$ ili u ekvivalentnom iznosu njutna (N), pri čemu je $10 \mathrm{~N}$ ekvivalentno jednom kilogramu. Test se nadovezivao na one zadatke koje su studenti rješavali na završnom kolokviju ili ispitu iz Fizike na kraju prvog semestra prve godine studija fizioterapije. Autori ovog mjernog instrumenta ujedno su autori ovog istraživanja.

Prvi zadatak bio je specifično povezan s područjem standardiziranog testa iz fizioterapijske procjene koji uključuje poznavanje i primjenu principa poluge.

1. pitanje. Fizioterapeut procjenjuje snagu mišića stražnje lože putem Manualnog mišićnog testa. Kod primjene otpora za ocjenu 4 primjenjuje opterećenje na distalni dio natkoljenice od 1 kilogram. Koliko mora biti opterećenje (izraženo u kg) koje fizioterapeut mora primijeniti na distalnom dijelu potkoljenice, a odgovarao bi opterećenju za ocjenu 5 ?

Odgovor: $1 \mathrm{~kg}(10 \mathrm{~N})$

$\mathrm{U}$ drugom zadatku naveden je primjer vertikalizacije pacijenta s izravnim objašnjenjem i svođenjem primjera na numerički zadatak s polugom.

2. pitanje. Kod postupka vertikalizacije pacijenta terapeut se koristi snagom svojih leđnih mišića kako bi pacijenta podigao na noge. Pritom se događa efekt poluge gdje kralježnica služi kao oslonac, leđni mišići s jedne strane oslonca (kralježnice) djeluju silom prema dolje i, kao efekt, s druge strane oslonca torzo terapeuta i pacijent podižu se prema gore. Razmotrimo slučaj kad je masa pacijenta $80 \mathrm{~kg}$, a udaljenost između oslonca (kralježnice) terapeuta i težišta pacijenta pola metra. $\mathrm{U}$ pojednostavljenom slučaju, udaljenost je hvatišta ekstenzornih mišića od kralježnice fizioterapeuta oko $2,5 \mathrm{~cm}$. Koliko je okvirno opterećenje na ekstenzorne mišiće fizioterapeuta?

\section{Odgovor: $16000 \mathrm{~N}$ (1600 kg)}

Treći je zadatak ispitivao razumijevanje pojma uzgona u slučaju plutanja tijela u vodi.

3. pitanje. Pacijent ima masu od $120 \mathrm{~kg}$. Kolika je njegova efektivna težina (sila kojom djeluje na pod) ako se nalazi u bazenu i uronjen je u vodu do razine umbilicusa?

Odgovor: $600 \mathrm{~N}(60 \mathrm{~kg})$

Četvrti zadatak ispituje primjenu elektroterapijskih procedura i traži poznavanje osnovnih svojstava tvari kod provođenja električne struje.

4. pitanje. Zašto se kod primjene elektroterapijskih procedura elektrode uvijek oblažu vlažnim oblogom?
a) zbog hlađenja
b) zbog kemijske ravnoteže
c) zbog električnog otpora
d) zbog higijene

\section{Odgovor: c)}

U petom zadatku ispituje se funkcionalna procjene hoda kroz zadatak povezan s jednolikim gibanjem.

5. pitanje. Funkcionalna procjena hoda jedna je od najčešće korištenih metoda u svrhu procjene rezultata i ishoda fizioterapijskog procesa. Jedan je od parametara koje fizioterapeut primjenjuje u svrhu analize hoda i brzina hoda. Ako je prosječna brzina hoda osobe starije životne dobi $4,5 \mathrm{~km} / \mathrm{h}$, koliko je vremena potrebno da se tom brzinom prijeđe put od pet metara?

\section{Odgovor: $4 \mathrm{~s}$}




\section{Postupak}

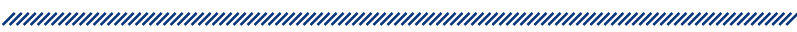

Proces prikupljanja podataka započeo je zahtjevom za odobrenje istraživanja Etičkog povjerenstva Zdravstvenog veleučilišta u Zagrebu. Nakon dobivanja suglasnosti za istraživanje, započelo se s podjelom materijala. Istraživanje je provedeno u prostorima Zdravstvenog veleučilišta Zagreb u rujnu i listopadu 2016. godine. Ciljani su uzorak sudionici koji su u vrijeme provođenja istraživanja bili studenti druge i treće godine studija fizioterapije koji su položili ispit iz predmeta Fizika. Mjerni instrument sadržavao je upute s osnovnim informacijama o istraživanju. Svim sudionicima predočili su se razlozi i postupci istraživanja. Cijeli postupak bio je anoniman, čime se jamči sigurnost identiteta sudionika, odnosno identifikacijski podaci u ovom istraživanju ne postoje. Svaki je sudionik u bilo kojem trenutku imao pravo odustati od istraživanja.

\section{Rezultati}

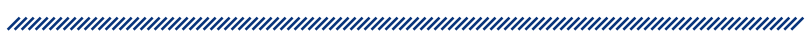

\section{Sociodemografski podaci ispitanika}

U istraživanju su sudjelovala 92 studenta druge (52,2\%) i treće $(47,8 \%)$ godine studija fizioterapije. Sociodemografske karakteristike sudionika u ovom istraživanju prikazane su u tablicama 1 i 2 . Većina sudionika bila je ženskog spola ( $84,8 \%)$, a osobe muškog spola obuhvaćale su 15,2\% populacije uzorka. Dob ispitanika kretala se od 19 do 29 godina $M=20,90 ; S D=1,618$ ). Kako je vidljivo u tablicama 1 i 2 , na ukupnom uzorku najveći broj studenata, 40 od 92 ili 43,5\%, položio je ispit iz kolegija Fizika s ocjenom izvrstan sa srednjom vrijednošću $M=4,24 ; S D=0,790$. Najveći broj studenata na drugoj godini, 42 od 48 ili $87,5 \%$, položio je ispit iz kolegija Fizika s ocjenom vrlo dobar i ocjenom izvrstan ( $M=4,29$; $\mathrm{SD}=0,683$ ) te ocjenu dovoljan nema nijedan ispitanik. Na trećoj godini raspon ocjena seže od ocjene dovoljan do ocjene izvrstan ( $M=4,18 ; S D=0,896)$.

$\mathrm{U}$ ovom istraživanju ispitivane su i čestice o procjeni znanja o utjecaju fizikalnih zakonitosti u svrhu objektivizacije i poboljšanja kvalitete fizioterapijskog procesa,

\begin{tabular}{|c|c|c|}
$\begin{array}{c}\text { Tablica 1. Sociodemografske karakteristike } \\
\text { sudionika cijelog uzorka }\end{array}$ \\
\hline Spol & $\mathrm{N}$ & $\%$ \\
\hline Muški & 14 & 15,2 \\
\hline Ženski & 78 & 84,8 \\
\hline Ukupno & 92 & 100,0 \\
\hline Godina studija & $\mathrm{N}$ & $\%$ \\
\hline Druga godina studija fizioterapije & 48 & 52,2 \\
\hline Treća godina studija fizioterapije & 44 & 47,8 \\
\hline Ukupno & 92 & 100,0 \\
\hline Završna ocjena iz kolegija Fizika & $\mathrm{N}$ & $\%$ \\
\hline Ocjena 2 (dovoljan) & 2 & 2,2 \\
\hline Ocjena 3 (dobar) & 14 & 15,2 \\
\hline Ocjena 4 (vrlo dobar) & 36 & 39,1 \\
\hline Ocjena 5 (izvrstan) & 40 & 43,5 \\
\hline Ukupno & 92 & 100,0 \\
\hline
\end{tabular}

\begin{tabular}{|c|c|c|c|}
\hline & Spol & $\mathrm{N}$ & $\%$ \\
\hline \multirow{3}{*}{$\begin{array}{l}\text { Druga } \\
\text { godina }\end{array}$} & Muški & 10 & 20,8 \\
\hline & Ženski & 38 & 79,2 \\
\hline & Ukupno & 48 & 100,0 \\
\hline \multirow{3}{*}{$\begin{array}{l}\text { Treća } \\
\text { godina }\end{array}$} & Muški & 4 & 9,1 \\
\hline & Ženski & 40 & 90,9 \\
\hline & Ukupno & 44 & 100,0 \\
\hline \multicolumn{2}{|c|}{ Završna ocjena iz kolegija Fizika } & $\mathrm{N}$ & $\%$ \\
\hline \multirow{4}{*}{$\begin{array}{l}\text { Druga } \\
\text { godina }\end{array}$} & Ocjena 3 (dobar) & 6 & 12,5 \\
\hline & Ocjena 4 (vrlo dobar) & 22 & 45,8 \\
\hline & Ocjena 5 (izvrstan) & 20 & 41,7 \\
\hline & Ukupno & 48 & 100,0 \\
\hline \multirow{5}{*}{$\begin{array}{l}\text { Treća } \\
\text { godina }\end{array}$} & Ocjena 2 (dovoljan) & 2 & 4,5 \\
\hline & Ocjena 3 (dobar) & 8 & 18,2 \\
\hline & Ocjena 4 (vrlo dobar) & 14 & 31,8 \\
\hline & Ocjena 5 (izvrstan) & 20 & 45,5 \\
\hline & Ukupno & 44 & 100,0 \\
\hline
\end{tabular}

stav o važnosti poznavanja fizikalnih zakonitosti u kreiranju fizioterapijskog procesa te dostupnost stručne i znanstvene literature o ulozi fizikalnih zakonitosti u okviru fizioterapijskog procesa, čiji su rezultati prikazani u tablicama 3, 4 i 5. Iz rezultata je vidljivo kako prilikom procjene znanja o utjecaju fizikalnih zakonitosti u svrhu 
Tablica 3. Procjena znanja o utjecaju fizikalnih zakonitosti u svrhu objektivizacije i poboljšanja kvalitete fizioterapijskog procesa na cijelom uzorku

\begin{tabular}{|c|c|}
\hline Aritmetička sredina & 3,02 \\
\hline Medijan & 3,00 \\
\hline Mod & 3 \\
\hline Standardna devijacija & 0,683 \\
\hline Minimum & 2 \\
\hline Maksimum & 5 \\
\hline
\end{tabular}

Tablica 4. Procjena važnosti poznavanja fizikalnih zakonitosti u kreiranju fizioterapijskog procesa na cijelom uzorku

\begin{tabular}{|c|c|}
\hline Aritmetička sredina & 3,88 \\
\hline Medijan & 4,00 \\
\hline Mod & 4 \\
\hline Standardna devijacija & 0,823 \\
\hline Minimum & 2 \\
\hline Maksimum & 5 \\
\hline
\end{tabular}

Tablica 5. Procjena dostupnosti stručne

i znanstvene literature o ulozi fizikalnih zakonitosti u okviru fizioterapijskog procesa na cijelom uzorku

\begin{tabular}{|c|c|}
\hline Aritmetička sredina & 3,08 \\
\hline Medijan & 3,00 \\
\hline Mod & 3 \\
\hline Standardna devijacija & 0,730 \\
\hline Minimum & 1 \\
\hline Maksimum & 5 \\
\hline
\end{tabular}

objektivizacije i poboljšanja kvalitete fizioterapijskog procesa više od polovice studenata daje ocjenu 3 prema Likertovoj skali ( $M=3,02 ; S D=0,683)$. Važnost poznavanja fizikalnih zakonitosti u kreiranju fizioterapijskog procesa studenti ocjenjuju na skali od 1 do 5 ocjenom $3(M=3,88, S D=0,823)$, dok dostupnost stručne i znanstvene literature tematski povezane s ulogom fizikalnih zakonitosti u okviru fizioterapijskog procesa studenti također ocjenjuju ocjenom 3 ( $M=3,08$; SD = 0,730). Ovakva distribucija rezultata vidljiva je i ako promatramo uzorak ovisno o godini studija koju pohađaju.

\begin{tabular}{|c|c|c|}
$\begin{array}{c}\text { Tablica 6. Frekvencije točnih/netočnih } \\
\text { odgovora na pitanja u testu na cijelom } \\
\text { uzorku }\end{array}$ \\
\hline 1. pitanje & $\mathrm{N}$ & $\%$ \\
\hline Točan odgovor & 41 & 44,6 \\
\hline Netočan odgovor & 51 & 55,4 \\
\hline Ukupno & 92 & 100,0 \\
\hline 2. pitanje & $\mathrm{N}$ & $\%$ \\
\hline Točan odgovor & 15 & 16,3 \\
\hline Netočan odgovor & 77 & 83,7 \\
\hline Ukupno & 92 & 100,0 \\
\hline 3. pitanje & $\mathrm{N}$ & $\%$ \\
\hline Točan odgovor & 16 & 17,4 \\
\hline Netočan odgovor & 76 & 82,6 \\
\hline Ukupno & 92 & 100,0 \\
\hline 4. pitanje & $\mathrm{N}$ & $\%$ \\
\hline Točan odgovor & 89 & 96,7 \\
\hline Netočan odgovor & 3 & 3,3 \\
\hline Ukupno & 92 & 100,0 \\
\hline 5. pitanje & $\mathrm{N}$ & $\%$ \\
\hline Točan odgovor & 58 & 63,0 \\
\hline Netočan odgovor & 34 & 37,0 \\
\hline Ukupno & 92 & 100,0 \\
\hline & & \\
\hline
\end{tabular}

\section{Frekvencije odgovora na pitanja u testu}

Kako bi se dobio odgovor na prvi cilj istraživanja, koji je bio ispitati razinu poznavanja fizikalnih zakonitosti u okviru fizioterapijskog procesa, prikazani su osnovni deskriptivni parametri omjera točnih i netočnih odgovora za svako pitanje unutar testa.

Na ukupnom uzorku može se uočiti da su ispitanici, neovisno o godini studija, većinom točno odgovorili na zadnja dva pitanja (tablica 6). Na prvo pitanje, povezano $s$ fizioterapijskom procjenom uz primjenu principa poluge, $44,6 \%$ studenata odgovorilo je točno. Na drugo pitanje, koje je ispitivalo postupak vertikalizacije pacijenta, 16,3\% studenata odgovorilo je točno. Na treće pitanje, koje je ispitivalo razumijevanje pojma uzgona u slučaju plutanja tijela u vodi, $17,4 \%$ studenata odgovorilo je točno. Na četvrto pitanje, koje ispituje kontekst primjene elektroterapijskih procedura i traži poznavanje osnovnih svojstava tvari kod provođenja električne struje, 96,7 \% studenata točno je odgovorilo, dok je na peto pitanje, koje je kroz funkcionalnu procjenu hoda zahtijevalo od studenata numerički izračun povezan $\mathrm{s}$ 
jednolikim gibanjem, $63 \%$ studenata odgovorilo točno. $U$ tablici 7 možemo vidjeti deskriptivne vrijednosti ukupnog broja točnih odgovora na cijelom uzorku $(M=2,38 ; S D=1,108)$.

\begin{tabular}{|c|c|}
$\begin{array}{c}\text { Tablica 7. Deskriptivni prikaz broja točnih } \\
\text { odgovora na cijelom uzorku }\end{array}$ \\
\hline Aritmetička sredina & 2,38 \\
\hline Medijan & 2,00 \\
\hline Mod & 2 \\
\hline Standardna devijacija & 1,108 \\
\hline Minimum & 0 \\
\hline Maksimum & 5 \\
\hline
\end{tabular}

Iz rezultata prikazanih u tablici 8 može se uočiti kako su studenti druge godine u većem postotku $(60,4 \%)$ točno odgovorili na 1. pitanje o fizioterapijskoj procjeni uz primjenu principa poluge u odnosu na studente treće godine studija ( $27,3 \%)$, pri čemu je ta razlika statistički značajna (hi-kvadrat $=10,20 ; \mathrm{df}=1 ; \mathrm{p}<0,01$ ).
Ovakva distribucija rezultata javlja se i kod 2. pitanja (tablica 9) o vertikalizaciji pacijenta, gdje je udio točnih odgovora statistički značajno veći kod studenata druge godine studija $(29,2 \%)$ nego kod studenata treće godine $(2,3 \%$; hi-kvadrat $=12,16 ; \mathrm{df}=1 ; \mathrm{p}<0,01)$.

Nije nađena statistički značajna razlika (tablica 10) između omjera točnih i netočnih odgovora s obzirom na godinu studija na 3 . pitanju koje je ispitivalo razumijevanje pojma uzgona u slučaju plutanja tijela u vodi (hi-kvadrat $=0,55 ; \mathrm{df}=1 ; \mathrm{p}>0,05$ ), kao ni na 4. pitanju (tablica 11), koje je ispitivalo razumijevanje važnosti vlažnog obloga elektroda prilikom primjene elektroterapijskih procedura (hi-kvadrat $=0,44 ; \mathrm{df}=1 ; \mathrm{p}>0,05$ ).

Iz tablice 12 može se vidjeti kako su studenti druge godine u većem postotku ( $83,3 \%$ ) točno odgovorili na 5 . pitanje, gdje se od studenata traži poznavanje jednolikog gibanja kroz numerički zadatak u primjeru funkcionalne procjene hoda starije osobe, $u$ odnosu na studente treće godine studija ( $27,3 \%)$, pri čemu je ta razlika statistički značajna (hi-kvadrat $=17,73 ; d f=1 ; p<0,01$ ).

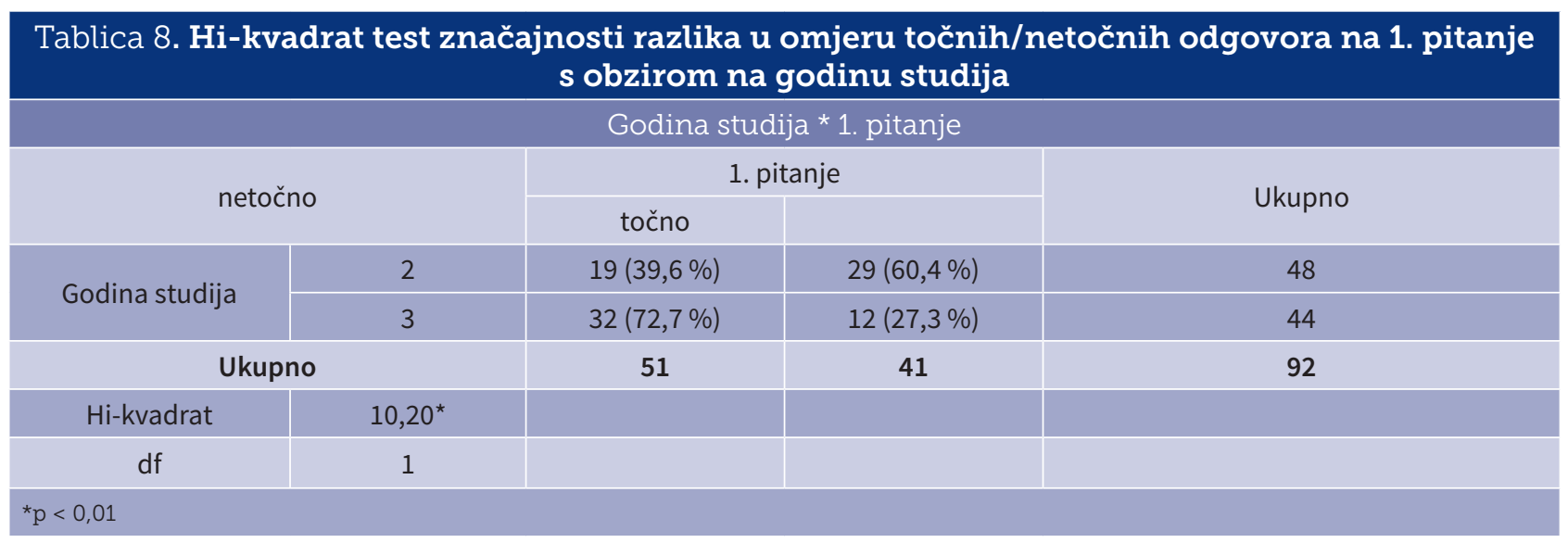

\begin{tabular}{|c|c|c|c|c|}
\hline \multicolumn{5}{|c|}{ Godina studija * 2. pitanje } \\
\hline \multirow{2}{*}{\multicolumn{2}{|c|}{ netočno }} & \multicolumn{2}{|c|}{ 2. pitanje } & \multirow{2}{*}{ Ukupno } \\
\hline & & točno & & \\
\hline \multirow{2}{*}{ Godina studija } & 2 & $34(70,8 \%)$ & $14(29,2 \%)$ & 48 \\
\hline & 3 & $43(97,7 \%)$ & $1(2,3 \%)$ & 44 \\
\hline \multicolumn{2}{|c|}{ Ukupno } & 77 & 15 & 92 \\
\hline Hi-kvadrat & $12,16^{*}$ & & & \\
\hline $\mathrm{df}$ & 1 & & & \\
\hline
\end{tabular}




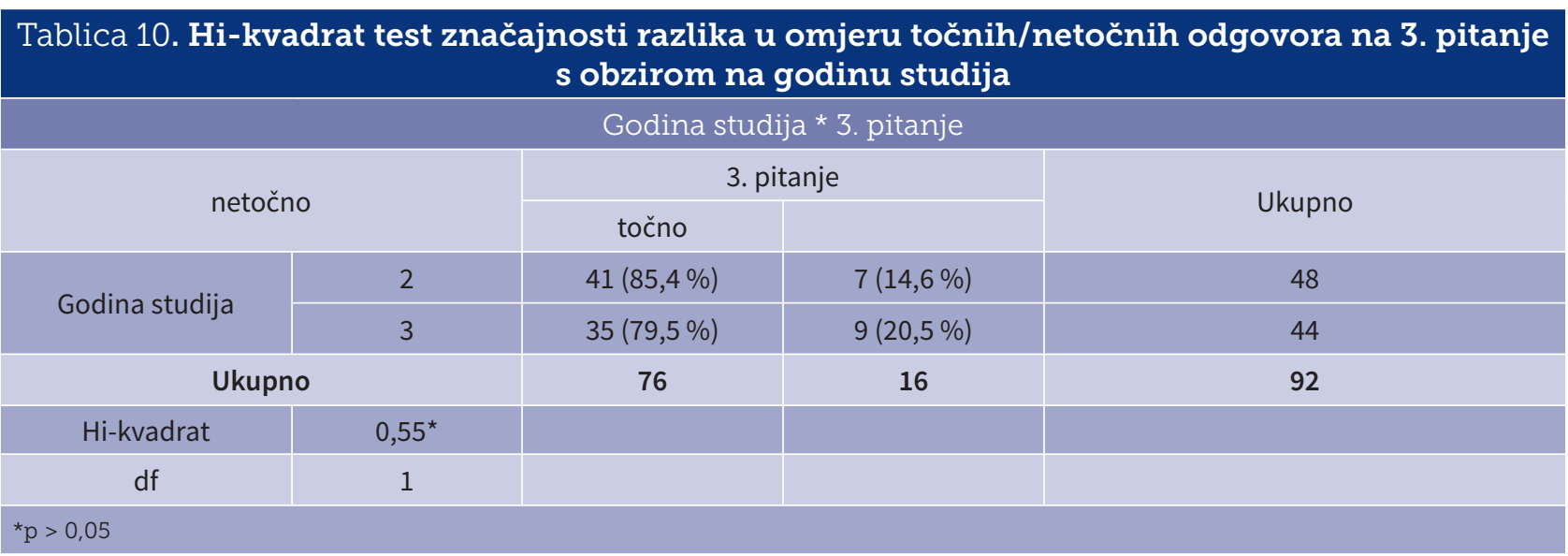

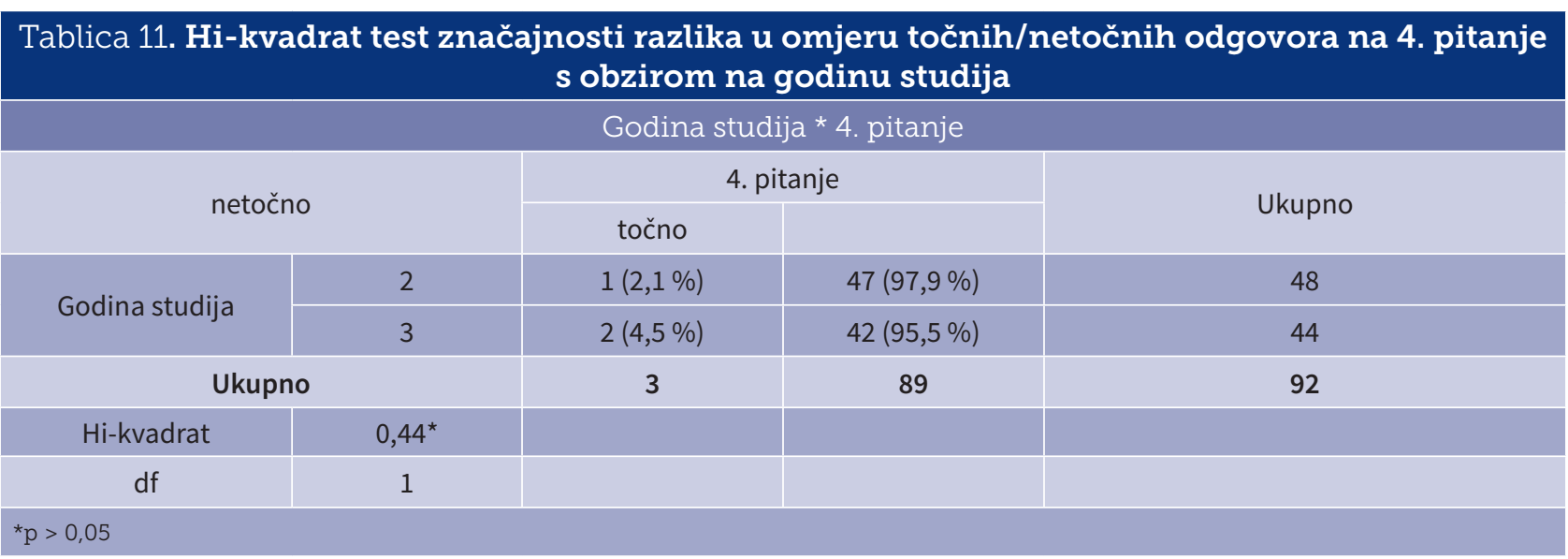

\begin{tabular}{|c|c|c|c|c|}
\hline & & Godina s & 5. pitanje & \\
\hline & & & & Illunno \\
\hline & & točno & & 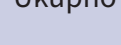 \\
\hline Godin studiiz & 2 & $8(16,7 \%)$ & $40(83,3 \%)$ & 48 \\
\hline & 3 & $26(59,1 \%)$ & $18(40,9 \%)$ & 44 \\
\hline Uk & & 34 & 58 & 92 \\
\hline Hi-kvadrat & $17,73^{*}$ & & & \\
\hline$d f$ & 1 & & & \\
\hline & & & & \\
\hline
\end{tabular}

Iz rezultata u tablici 13 može se vidjeti da je najveći broj studenata na drugoj godini studija dao tri točna odgovora (30,4\%), dok je najviše studenata treće godine dalo dva točna odgovora (38,6\%).
Razlike analiziranih skupina u procjeni poznavanja fizikalnih zakonitosti u kreiranju fizioterapijskog procesa

Kako bi se odgovorilo na drugi cilj istraživanja, provjerena je povezanost sociodemografskih karakteristika studenata fizioterapije i njihova dosadašnjeg uspjeha na predmetu Fizika u odnosu na razinu znanja fizikalnih 
zakonitosti u okviru fizioterapijskog procesa. Rezultati neparametrijskog Mann-Whitneyjeva U-testa, prikazani u tablici 14, pokazali su da ne postoji statistički značajna razlika u ukupnom zbroju točnih odgovora s obzirom na spol sudionika (Mann-Whitneyjev $U=461,500 ; p>0,05$ ).

\begin{tabular}{|c|c|c|c|}
\hline & & $\mathrm{N}$ & $\%$ \\
\hline \multirow{6}{*}{$\begin{array}{l}\text { Druga } \\
\text { godina }\end{array}$} & 1 točan odgovor & 5 & 10,4 \\
\hline & 2 točna odgovora & 11 & 22,9 \\
\hline & 3 točna odgovora & 20 & 41,7 \\
\hline & 4 točna odgovora & 10 & 20,8 \\
\hline & 5 točnih odgovora & 2 & 4,2 \\
\hline & Ukupno & 48 & 100,0 \\
\hline \multirow{6}{*}{$\begin{array}{l}\text { Treća } \\
\text { godina }\end{array}$} & Nijedno pitanje odgovoreno & 2 & 4,5 \\
\hline & 1 točan odgovor & 15 & 34,1 \\
\hline & 2 točna odgovora & 17 & 38,6 \\
\hline & 3 točna odgovora & 7 & 15,9 \\
\hline & 4 točna odgovora & 3 & 6,8 \\
\hline & Ukupno & 44 & 100,0 \\
\hline
\end{tabular}

Također, nije dobivena statistički značajna povezanost (tablica 15) zbroja točnih odgovora i završne ocjene iz kolegija Fizika (Spearmanov rho $=0,055, \mathrm{p}>0,05$ ), procjene vlastitog znanja u području fizike (Spearmanov rho $=0,139 ; p>0,05)$ te stavom o važnosti poznavanja fizikalnih procesa (Spearmanov rho $=0,123 ; p>0,05$ ).

Pri analizi razlika rezultata u ukupnom zbroju točnih odgovora s obzirom na godinu studija primijenjen je neparametrijski Mann-Whitneyjev U-test (tablica 16). Iz rezultata je vidljivo da u broju točnih odgovora postoji statistički značajna razlika s obzirom na godinu studija, pri čemu su studenti druge godine studija fizioterapije dali više točnih odgovora u odnosu na studente treće godine (Mann-Whitneyjev $U=521,000, p<0,01$ ).

\section{Diskusija}

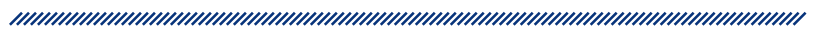

Ovo istraživanje provjerava elementarna znanja fizikalnih zakonitosti i ne ulazi u njihovo dublje poznavanje. $U$ uvodnom dijelu istraživanja ispitivali su se ulazni parametri kao što je dosadašnji uspjeh studenata iz kolegija Fizika, njihova procjena vlastitog znanja te stav o važnosti poznavanja fizikalnih procesa. Na ukupnom uzorku najveći broj studenata položio je ispit iz kolegija Fizika s ocjenom izvrstan. Važnost poznavanja fizikalnih zakonitosti u kreiranju fizioterapijskog procesa studenti ocjenjuju na skali od 1 do 5 ocjenom 3. Prema rezultatima do-

\begin{tabular}{|c|c|c|c|c|c|}
\hline \multicolumn{6}{|c|}{ Test sume rangova } \\
\hline & Spol & $\mathrm{N}$ & Prosječni rang & Suma rangova & $\begin{array}{c}\text { Mann- } \\
\text { Whitneyjev U }\end{array}$ \\
\hline \multirow{3}{*}{$\begin{array}{l}\text { Zbroj točnih } \\
\text { odgovora }\end{array}$} & Muški & 14 & 52,54 & 735,5 & \multirow{2}{*}{$461,500^{\star}$} \\
\hline & Ženski & 78 & 45,42 & 3542,5 & \\
\hline & Ukupno & 92 & & & \\
\hline${ }^{*} p>0,05$ & & & & & \\
\hline
\end{tabular}

Tablica 15. Spearmanova rho-korelacija Zbroja točnih odgovora i ostalih ispitanih varijabli

\begin{tabular}{|c|c|c|c|c|c|}
\hline & 1 & 2 & 3 & 4 & 5 \\
\hline 1. Završna ocjena iz kolegija Fizika & 1 & 0,15 & $0,214^{*}$ & 0,063 & 0,055 \\
\hline 2. Procjena znanja o utjecaju fizikalnih zakonitosti & & 1 & $0,324^{\star *}$ & $0,262^{*}$ & 0,139 \\
\hline 3. Smatrate li potrebnim poznavanje fizikalnih zakonitosti? & & & 1 & 0,138 & 0,123 \\
\hline 4. Procijenite dostupnost stručne i znanstvene literature. & & & & 1 & 0,18 \\
\hline 5. Zbroj točnih odgovora & & & & & 1 \\
\hline
\end{tabular}




\begin{tabular}{l}
\multicolumn{6}{|c|}{ Tablica 16. Test sume rangova ispitivanih skupina u ukupnom zbroju točnih odgovora s } \\
obzirom na godinu studija
\end{tabular}

bivenima u ovom istraživanju može se vidjeti da najveći broj studenata, neovisno o godini studija koju pohađa, ima dva točna odgovora te bi položio ispit (tablica 7).

Ako se promatra rezultat točnih odgovora na testu, postoji statistički značajna razlika s obzirom na godinu studija, pri čemu su studenti druge godine studija fizioterapije dali više točnih odgovora u odnosu na studente treće godine. Objašnjenje ovakvog rezultata istraživanja moguće je interpretirati na način da je znanje koje se stječe u okviru općeobrazovnih kolegija uglavnom teorijsko i na prvi pogled nepovezano s praktičnom primjenom. Ovaj je problem već dugo poznat i zato se u obrazovnim i pedagoškim krugovima već nekoliko desetljeća naglašava potreba približavanja teorije praksi, to jest ilustriranje prirodnih zakonitosti praktičnim primjerima iz svakodnevnog života ako je riječ o općem obrazovanju, odnosno primjerima iz struke ako je riječ o stručnom obrazovanju. Međutim, drugi je dio problema to što svako znanje treba primjenjivati u različitim problemskim situacijama, a nakon što polože ispit iz kolegija Fizika studenti se više ne susreću s kvantitativnim problemima ove vrste. lako se u daljnjem obrazovanju primjenjuje princip poluge, taj princip nije kvantificiran na isti način. Svi znaju da će se vrata lakše otvoriti ako ih se gurne bliže slobodnom kraju, ali malo tko razmišlja o omjerima sila u slučajevima kad se hvatišta sile nalaze na različitim mjestima. Može se raspravljati koliko je to zapravo važno za svakodnevnu primjenu, ali bilo bi dobro biti svjestan konkretnih vrijednosti sile kad je riječ o tjelesnim oštećenjima. S ovim je konzistentan rezultat da su studenti druge godine studija imali bolje rezultate od studenata treće godine: jednostavno, manje je vremena prošlo od njihova polaganja ispita iz predmeta Fizika i imali su manje vremena da zaborave informacije koje su naučili i znali.

Vertikalna, horizontalna i dijagonalna koherentnost i konzistentnost studijskog programa omogućuje stu- dentima rješavanje problema po principu problem solving. Kompetencije za pojedini studijski predmet predstavljaju standardizirane oblike znanja i vještina, uključuju i razinu razumijevanja, odgovornosti te etičkih vrijednosti ${ }^{5,6}$. Kompetencije se razvijaju i nadograđuju, uključuju teorijsko znanje i razumijevanje, praktičnu primjenu znanja o tome kako djelovati te znanje o tome kako biti i živjeti s drugima u društvenom kontekstu. Kako je učenje dinamičan proces, tako su i kompetencije koje se stječu sposobnost u nastajanju, mijenjanju pa govorimo o generičkim i područno specifičnim kompetencijama ${ }^{5,6}$.

Prema autorici Preglej ${ }^{7}$, obrazovna istraživanja nisu razvijena unutar priznate znanosti zbog krute granice između discipline, maskulinizacije istraživanja i feminizacije nastave, kao i naslijeđene predrasude o istraživanjima u nastavi ${ }^{7,8}$. Obrazovna su istraživanja najvećim dijelom ograničena na psihološku perspektivu, tj. na zanimanje za učenje, motivaciju, procjenu i upravljanje procesom učenja. Znanost o obrazovanju mora imati svoj temelj u interdisciplinarnosti. To zahtijeva kooperativne napore znanstvenika različitih znanstvenih grana, nastavnika specijalista za nastavu određene struke, djece, metodičara, pedagoga, psihologa i sociologa u skladu s društvenim, klasnim te rasnim i kulturnim vrijednostima i običajima. Radeći zajedno, takvi timovi mogli bi dizajnirati testiranje programa i nastavnih metoda koje bi bilo ažurirano i razvojno primjereno ${ }^{7,8}$.

Rezultati ovog istraživanja omogućuju izradu smjernica povezanih s oblikovanjem strategija za unaprjeđenje kvalitete nastavnog plana i programa predmeta Fizika, kao i ostalih predmeta na studiju fizioterapije, u cilju boljeg razumijevanja i sustavnije primjene fizikalnih zakonitosti u fizioterapijskom procesu. Kroz interdisciplinarni pristup predmetnih nastavnika iz područja fizioterapije i fizike studentima fizioterapije omogućit će se razvoj generičkih i predmetno specifičnih kompetencija 
i pripremiti ih za zahtjeve tržišta rada koje u fizioterapijskom procesu zahtijeva konstantno prilagođavanje parametara terapije konkretnoj situaciji s pacijentom.

\section{Mogući prijedlozi i rješenja u cilju poboljšanja nastavnog plana i programa studija fizioterapije u smislu boljeg poznavanja i primjene fizikalnih zakonitosti u fizioterapijskom procesu}

Potrebno je naglasiti važnost kvantifikacije fizikalnih zakonitosti u razumijevanju generalno, a posebno $u$ nastavi i primjeni u okviru fizioterapijskog procesa. Nije isto reći „osoba uronjena u vodu ima manju težinu” i „osoba mase $100 \mathrm{~kg}$ uronjena u vodu do polovice ima težinu ekvivalentnu masi od 50 kg", kao što nije isto reći ni „mišić je pod velikim opterećenjem” i „mišić je pod opterećenjem od pola tone". Međutim, da bi se zaista usvojile kvantificirane spoznaje o prirodnim zakonitostima, tu nije dovoljno imati jedan kolegij koji se pohađa tijekom jednog semestra, a onda, kao što se vidi iz podataka ovog istraživanja, polako zaboravi, nego je potrebno neprestano primjenjivati i povezivati fizikalne zakonitosti s primjerima iz nastave i prakse koji su dio nastavnog kurikuluma stručnih predmeta.

Praktična je vrijednost ovog rada specifičnost uzorka koji obuhvaća studente fizioterapije te tema istraživanja koja ispituje dinamičku vezu u procesu učenja u okviru područja fizike i fizioterapije. Prednost ovog istraživanja također je homogenost uzorka, koji je obuhvatio studente koji su položili ispit iz kolegija Fizika na prvoj godini.

Ograničavajući je čimbenik u istraživanju nedostatak longitudinalnih i intervencijskih studija povezanih $\mathrm{s}$ područjem fizike u okviru fizioterapijskog procesa. Metodološki je nedostatak u ovom istraživanju prigodni uzorak koji obuhvaća studente stručnog studija fizioterapije te veličina uzorka koja ne dopušta generalizaciju rezultata. U novim bi istraživanjima bilo potrebno validirati metrijske karakteristike ovog testa na populaciji studenata stručnih i sveučilišnih programa studija fizioterapije. Longitudinalnim studijama koje bi se provodile kroz dulji period dobili bi se korisni podaci o tome kako studenti fizioterapije razumiju fizikalne zakonitosti u kreiranju fizioterapijskog procesa, što bi rezultiralo poboljšanjem kvalitete nastavnog plana i programa studija fizioterapije.

\section{Zaključak}

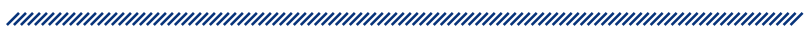

Poznavanje fizike u fizioterapijskom procesu ili u bilo kojem drugom području nije samo sebi svrhom, već je potrebno kako bi se bolje razumjele prirodne zakonitosti koje diktiraju ponašanje ljudskog tijela kad ga se dovede u određene okolnosti i može nam pomoći da bolje utvrdimo koji će terapijski postupci dovesti do objektivizacije i povećanja kvalitete fizioterapijskog procesa u određenoj situaciji. Zbog toga je učenje fizike na studiju fizioterapije ključan preduvjet za razumijevanje fizikalnih zakonitosti. No ograničavanje učenja fizike samo na kolegij Fizika u prvom semestru očito nije dovoljno, jer se do treće godine studija neke osnovne stvari bez ponavljanja i, još važnije, bez upotrebe jednostavno zaborave. Ovo istraživanje pokazalo je statistički značajnu razliku u znanju fizike između studenata koji su kolegij odslušali jednu i dvije godine ranije. Ukupno $60 \%$ studenata točno je odgovorilo na dva ili tri od mogućih pet pitanja na testu. Rezultati istraživanja ukazuju da ne postoji statistički značajna povezanost točnih odgovara studenata s njihovom završnom ocjenom, samoprocjenom znanja iz područja fizike te dostupnošću stručne i znanstvene literature. Nepoznavanje fizikalnih zakonitosti rezultira fizioterapijskim procesom pri kojemu je nužno slijepo pridržavanje propisanih procedura bez mogućnosti prilagođavanja parametara konkretnoj situaciji, bez imalo fleksibilnosti. Istovremeno, poznavanje fizikalnih principa fizioterapeutu omogućuje objektivniju fizioterapijsku procjenu i korekciju pojedinih postupaka. Ekstrapolacijom se može doći do prilično realnih pretpostavki za razinu znanja fizike profesionalnih fizioterapeuta koji su diplomirali, našli posao i rade više godina. 


\section{Literatura}

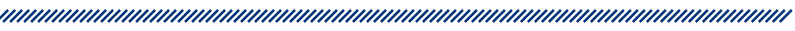

1. Zdravstveno veleučilište Zagreb. Fizika. U: Studijski program stručnog studija fizioterapije. Zagreb: Zdravstveno veleučilište; 2016. 33-35.

2. Beljo Lučić R, Buntić Rogić A, Dubravac Šigir M, Dželalija M, Hitrec S, Kovačević $S$, et al. Hrvatski kvalifikacijski okvir: Uvod u kvalifikacije. Zagreb: Vlada Republike Hrvatske, Ministarstvo znanosti, obrazovanja i športa; 2009.

3. Deluka-Tibljaš A, Karleuša B, Štimac Grandić I. Definiranje ishoda učenja na studijima građevinarstva Sveučilišta u Rijeci. Građevinar. 2011; 63(1): 1-10.

4. Roginić T. Fizika 1: udžbenik za 1. razred srednjih škola s dvogodišnjim programom fizike. Zagreb: Školska knjiga; 2009. 90-93.

5. Projekt Tuning [internet]. Uvod u projekt Uskladivanje obrazovnih struktura u Europi: Sveučilišni doprinos Bolonjskom procesu. Prosinac 2006. Dostupno na: http:// www.unideusto.org/tuningeu/images/stories/documents/General_brochure_Croatian_version_FINAL.pdf (pristupljeno 15.5.2017.).

6. Račić M. Modeli kompetencija za društvo znanja. Suvremene TEME. 2013; 6(1): 86-100.

7. Preglej L. Istraživanja u nastavi. Educatio Biologiae. 2014; 1: 100-116.

8. Elkind D. Educational Research and the Science of Education. Educ Psychol Rev. 1999; 11(3): 271-287. 


\section{KNOWLEDGE OF PHYSICAL LAWS IN THE CREATION OF THE PHYSIOTHERAPY PROCESS}

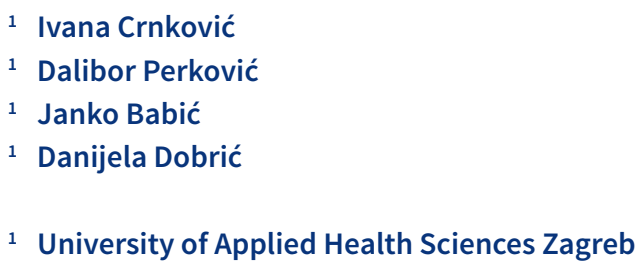

\section{Summary}

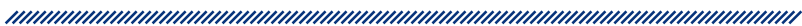

Physics is one of the key natural sciences in physiotherapy practice. The aim of this study was to examine the knowledge and application of physical laws in the physiotherapy process of undergraduate physiotherapy students. The research included 92 second-year and third-year students, who passed the course Physics in their first year of study. For the purpose of this research, a test was developed with tasks thematically related to the application of physical laws in the creation of the physiotherapy process.

According to the results, most students achieved very good (39.1\%) or excellent success $(43.5 \%)$ in the course Physics. The perceived level of knowledge about the impact of physical laws for the purpose of objectification and improvement of the quality of the physiotherapy process was assessed by students as good. In the total sample, two-thirds of students considered that knowledge of physical laws is important or very important in creating the physiotherapy process. A total of $60 \%$ of students correctly answered 2 or 3 out of the possible 5 questions in the test. The results show that there is a statistically significant difference in the number of correct answers; the students of the $2^{\text {nd }}$ year of physiotherapy gave more accurate answers than the students of the $3^{\text {rd }}$ year. Research results indicate that there is no statistically significant correlation between the students' correct answers and their final assessment, self-assessment of knowledge in physics and the availability of professional and scientific literature.

The results of this research serve as a basis for the development of guidelines for designing strategies for improving the quality of the curriculum content of the course Physics at the Study of Physiotherapy in order to apply physical laws to the physiotherapy process.

Keywords: physical laws, physiotherapy process, physics 